\title{
PECULIARITIES OF PRODUCING AN ELECTROLYTIC IRON POWDER FROM ROLLING MANUFACTURE WASTE
}

\author{
Sofiya Pinchuk ${ }^{1}$, Alexander Vnukov ${ }^{1}$, Roman Cheranev ${ }^{1, *}$
}

https://doi.org/10.23939/chcht13.01.121

\begin{abstract}
The electrolytic iron powder with controlled shape and size of particles and required structural, physical and functional properties was synthesized. The electrolytic precipitation of dispersed iron was carried out using a steel soluble anode and a titanium cathode. Sulfate electrolyte was used; the shape of the cathode was a plate; the electrolysis time was $1 \mathrm{~h}$. Experimental studies were carried out using correlation-regression analysis. The average particle size and morphology were determined using optical microscopy. Based on the results of the experiments, polynomial models that adequately describe the established relationships of the parameters studied were obtained. The most significant factors are the circulation rate of the electrolyte, the cathodic current density, and the concentration of iron vitriol in the electrolyte.
\end{abstract}

Keywords: rolling manufactures waste, scale, iron powder, circulation rate, electrodeposition, current density, geometry of particles.

\section{Introduction}

One of the most important directions in the development of domestic production is resource saving, and introduction of low-waste and non-waste technologies. Powder metallurgy plays a significant role here, allowing to manufacture a number of products that can not be produced by traditional methods [1-3]. The consumption of metals in this case is reduced by $2-3$ times. The advantage of powdered technologies is that metal powders can be obtained directly from ore, concentrates, and from metallurgical production waste scale, swarf, etc. The preparation and synthesis methods, as well as the type of feedstock, substantially determine the properties of powders and their application area.

About 1 billion tons of man-caused waste are generated annually in Ukraine, including various types of mill scale (flaky particles of different thickness, consisting mainly of iron oxides) $[4,5]$. The most known methods of

\footnotetext{
${ }^{1}$ National Metallurgical Academy of Ukraine,

4, Gagarina Ave., Dnipro, Ukraine

*cheranovroman@gmail.com

(c) Pinchuk S., Vnukov A., Cheranev R., 2019
}

mill scale processing as a raw material for the production of iron powders are the electrolysis of aqueous solutions and the reduction of iron oxides [6,7].

Electrolysis has a number of advantages, especially when it is necessary to obtain a product with certain physico-chemical properties on a mass scale for different types of industries. The high dispersity, well-developed surface and dendritic shape of iron powder particles (Fig. 1) make it suitable for the production of cermets and for the synthesis of some special grades of electrical iron and porous antifriction materials [8-10]. The synthesized electrolytic iron powders with a bulk density within the range of $1.5-2.2 \mathrm{~g} / \mathrm{cm}^{3}$ have an advantage over powders with a small bulk density synthesized by chemical reduction methods. In addition, electrolytic iron powders have the ability to be pressed into strong briquettes and easily sintered $[11,12]$.

One of the most important consumer properties of metal powders is the stability of their chemical compositions. Usually, for the production of powder metal wares, the content of the base metal in powder is 98$99 \%$, and powders of even higher purity are required for the production of wares with special properties [13, 14]. The limiting content of impurities in powders is determined by their permissible content in the resulting product. The exception is oxides, which can be removed during sintering. In most powders the oxygen content of $0.2-1.5 \%$ is permitted, which corresponds to the content of oxides within 1-10\%. A higher content of oxides reduces the powder compressibility and molding strength, hampers sintering and deteriorates the mechanical properties of the resulting wares.

Electrolytic iron powders have a high degree of purity. In a number of cases, it is possible to synthesize powders containing up to $99.7 \%$ of iron. In highly dispersed electrolytic iron powders (particles size 2$10 \mu \mathrm{m})$ of such purity, there is no magnetic hysteresis, which makes this material extremely valuable in the electrical industry for manufacturing cores of high frequency installations, reel magnetic cores in telephony and telegraphy, switch brushes, induction coils and other products. 


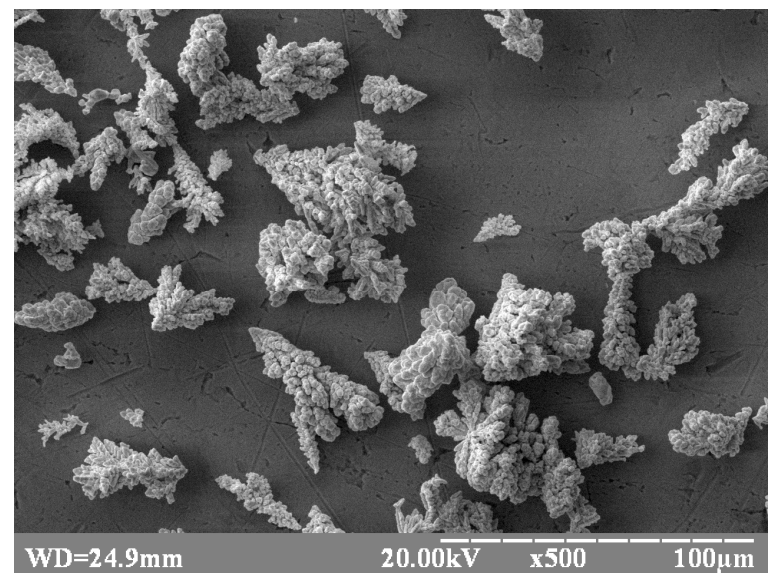

Fig. 1. Micrograph of electrolytic iron powder particles

However, the particular properties of iron cause a number of difficulties in the electrolytic synthesis of iron powder $[11,12,15]$.

Iron is an electronegative metal, so hydrogen is released from acidic solutions together with it. When working under such conditions, the current efficiency of iron powder is greatly reduced, and the quality of the cathode deposit is deteriorated as a result of hydrogen introduction into it. The latter circumstance necessitates an additional annealing operation. The more hydrogen in the deposit, the worse it can be crushed. Iron is capable of separation from solutions in the form of hydroxides; the latter can cause contamination of the powder, followed by difficulties in manufacturing a standard product and implementation of a continuous process.

In the electrolytic process, the powder uniformity regarding the granulometric composition is insufficient; therefore, such a powder is of little use in technologies where homogeneous dispersity is required.

To control the synthesis of powder with the required and predicted properties, it is necessary to understand the mechanisms of the combined influence of the electrodeposition process parameters on the structure and operational properties of the deposit.

In this connection, it is of considerable interest to quantify the impact not only of individual electrolysis parameters [11, 12, 15], but also their joined effect, which should be greater.

The aims of this research are to synthesize a chemically stable electrolytic iron powder with controlled shape and size of particles, with the required structural, physical and functional properties from the mill scale of rolling production; to evaluate the combined effect of electrolysis technological parameters, as well as the electrolyte composition on the properties of dispersed iron deposit, and to determine the efficiency of varying parameters in the synthesis of high pure iron powder.

\section{Experimental}

For the synthesis of dispersed cathode iron, we used electrolytes which were obtained by treating mill scale (JSC Interpipe-NTZ, Ukraine) with sulfuric acid. The chemical composition of the scale is shown in Table 1. The phase composition and morphology of the particles are shown in Figs. 2 and 3.

After scale treating with sulfuric acid the electrolytes were filtered and their chemical compositions were corrected according to the specified experimental conditions.

The process of electrolytic deposition was conducted using titanium insoluble cathode and soluble iron anodes according to the following regimes:

$60 \mathrm{~A} / \mathrm{dm}^{2}$;

- current density was varied from 40 to

- electrolyte temperature was varied from 313 to $353 \mathrm{~K}$

- circulation rate was varied from 100 to $700 \mathrm{rpm}$;

- cathode shape - plate;

- electrolysis time - $1 \mathrm{~h}$;

- Electrolyte composition (g/l): (160-300) $\mathrm{FeSO}_{4}+45 \mathrm{Na}_{2} \mathrm{SO}_{4}+(0-0.3) \mathrm{H}_{2} \mathrm{SO}_{4}$

After electrolysis completion, the cathode deposit was extracted from the bath, washed with running water and dried in a drying cabinet at $353 \mathrm{~K}$. The resulting iron sponge was ground in a planetary mill, with the rotational speed of $170 \mathrm{rpm}$.

Experiments were carried out in accordance with full factorial experiments (FFE), as well as with the use of correlation regression analysis.

The particle morphology was determined using optical and scanning electron microscopy. The phase composition of the feedstock and the resulting product was determined using a DRON-2 unit. The chemical composition of the materials was determined by mass spectroscopy.

\section{Results and Discussion}

\subsection{Effect of Electrolysis Technological Parameters and Electrolyte Composition on Physical Properties of Dispersed Iron}

In the first series of experiments we studied the combined effect of current density $\left(i, \mathrm{~A} / \mathrm{dm}^{2}\right)$, electrolyte temperature $\left(t,{ }^{\circ} \mathrm{C}\right)$ and electrolyte circulation rate $(v, \mathrm{rpm})$ on the particles average size $\left(d_{a v}, \mu \mathrm{m}\right)$ and current efficiency $(\eta, \%)$. In the second series of experiments the combined effect of current density, concentrations of 
sulfuric acid $\left(C\left(\mathrm{H}_{2} \mathrm{SO}_{4}\right), \mathrm{g} / \mathrm{l}\right)$, and iron vitriol $\left(C\left(\mathrm{FeSO}_{4}\right)\right.$, $\mathrm{g} / \mathrm{l})$ in the electrolyte on the average particle size and current efficiency was investigated. The matrices of the experiment plan and experimental results are presented in Tables 2 and 3 , respectively.
Based on the results of the experiments we created regression models adequately describing the investigated dependencies:

$$
\begin{aligned}
& d_{a v}=337.3-9.6 i-41.34 t-50.27 v- \\
& -10.25 i v+41.34 t v+2.65 i t v
\end{aligned}
$$

Table 1

Chemical composition of mill scale

\begin{tabular}{|c|c|c|c|c|c|c|c|c|}
\hline \multicolumn{9}{|c|}{ Components, wt \% } \\
\hline $\mathrm{Fe}_{\text {total }}$ & $\mathrm{Fe}_{2} \mathrm{O}_{3}$ & $\mathrm{FeO}$ & $\mathrm{SiO}_{2}$ & $\mathrm{MnO}$ & $\mathrm{S}$ & $\mathrm{P}$ & $\mathrm{C}$ & $\mathrm{O}_{2}$ \\
\hline 72.5 & 37.15 & 59.65 & 0.45 & 0.51 & 0.02 & 0.05 & 0.31 & 22.35 \\
\hline
\end{tabular}

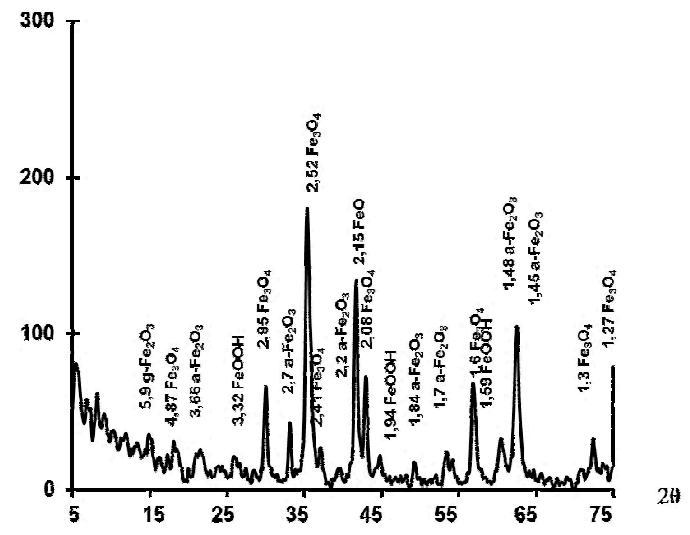

Fig. 2. Diffractogram of dispersed mill scale

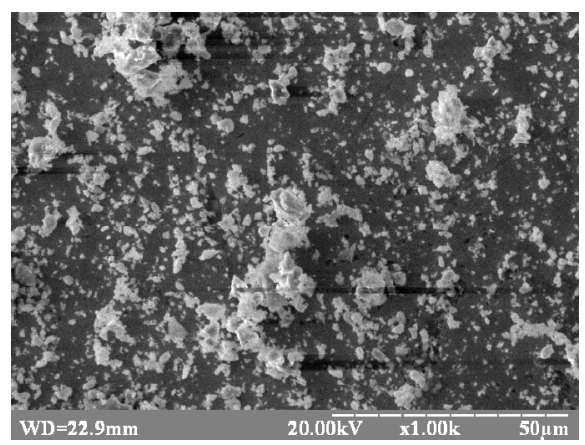

Fig. 3. Micrograph of mill scale particles

Plan and results of the $1^{\text {st }}$ series of experiments

\begin{tabular}{|c|c|c|c|c|c|}
\hline \multirow{2}{*}{ No. } & \multicolumn{3}{|c|}{ Parameters } & \multicolumn{2}{c|}{ Response functions } \\
\cline { 2 - 6 } & $i, \mathrm{~A} / \mathrm{dm}^{2}$ & $t,{ }^{\circ} \mathrm{C}$ & $v, \mathrm{rpm}$ & $d_{a v}, \mu \mathrm{m}$ & $\eta, \%$ \\
\hline 1 & 60 & 80 & 700 & 332 & 85 \\
\hline 2 & 40 & 80 & 700 & 303 & 86 \\
\hline 3 & 60 & 40 & 700 & 272 & 89 \\
\hline 4 & 40 & 40 & 700 & 265 & 83 \\
\hline 5 & 60 & 80 & 100 & 345 & 98 \\
\hline 6 & 40 & 80 & 100 & 212 & 78 \\
\hline 7 & 60 & 40 & 100 & 398 & 63 \\
\hline 8 & 40 & 40 & 100 & & \\
\hline
\end{tabular}

Plan and results of the $2^{\text {nd }}$ series of experiments

\begin{tabular}{|c|c|c|c|c|c|}
\hline \multirow{2}{*}{ No. } & \multicolumn{3}{|c|}{ Parameters } & \multicolumn{2}{c|}{ Response functions } \\
\cline { 2 - 6 } & $i, \mathrm{~A} / \mathrm{dm}^{2}$ & $C\left(\mathrm{H}_{2} \mathrm{SO}_{4}\right), \mathrm{g} / \mathrm{l}$ & $C\left(\mathrm{FeSO}_{4}\right), \mathrm{g} / \mathrm{l}$ & $d_{a v}, \mu \mathrm{m}$ & $\eta, \%$ \\
\hline 1 & 60 & 0,3 & 300 & 256 & 63 \\
\hline 2 & 40 & 0,3 & 300 & 280 & 85 \\
\hline 3 & 60 & 0 & 300 & 170 & 89 \\
\hline 4 & 40 & 0 & 300 & 350 & 75 \\
\hline 5 & 60 & 0,3 & 160 & 190 & 53 \\
\hline 6 & 40 & 0,3 & 160 & 120 & 80 \\
\hline 7 & 60 & 0 & 160 & 122 & 74 \\
\hline 8 & 40 & 0 & 160 & & \\
\hline
\end{tabular}




$$
\begin{gathered}
\eta=83.5+5.5 t v \\
d_{a v}=369+181 C\left(\mathrm{H}_{2} \mathrm{SO}_{4}\right)+44 i \cdot C\left(\mathrm{H}_{2} \mathrm{SO}_{4}\right)- \\
-84.33 i \cdot C\left(\mathrm{FeSO}_{4}\right) \\
\eta=69.9-7 i \cdot C\left(\mathrm{H}_{2} \mathrm{SO}_{4}\right)-9.833 i \cdot C\left(\mathrm{H}_{2} \mathrm{SO}_{4}\right) \cdot C\left(\mathrm{FeSO}_{4}\right)
\end{gathered}
$$

The electrolyte circulation has the most significant effect on the response functions. The increase in the circulation rate decreases the difference of iron ions concentration at the cathode and inside electrolyte. In this case, the reserve of discharging ions in the near-cathode layer increases, the formation and growth of crystals occurs more uniformly, and coarse-grained deposits of iron are formed (Figs. 4 and 5).

At high circulation rates the particles with a less developed surface are formed, while a high current density allows to obtain particles with a well-developed dendritic surface. Therefore, to obtain dispersed iron powders (including those obtained due to further grinding of the resulting deposit), it may be advisable to conduct the electrolysis process with high current density and low circulation rate of the electrolyte.

The increase in current density contributes to the increase of cathode deposit dispersion (Fig. 6). Moreover, with the increasing current density the influence of a group of factors that weaken the diffusion processes increases.

In particular, stirring of the electrolyte promotes intensive release of hydrogen and leads to an increase in convective currents, which are formed under the influence of the evolved Joule heat and the increasing rate of change in the iron ions concentration in the near-electrode layers of the electrolyte. Hydrogen, being reduced together with iron ions at the cathode during deposition of friable deposit, has a multifaceted effect on its formation and on the electrolysis process as a whole. The released hydrogen promotes the electrolyte stirring and affects the delivery of iron ions to the cathode, and thus the dispersion and structure of the deposited particles. As a result of intensive hydrogen release, the electrolyte $\mathrm{pH}$ is changed in the near-cathode layer, up to the value of hydroxides and basic metal salts formation. The resulting colloidal particles of the suspension are adsorbed on the crystal faces, essentially affecting the dispersity and dendriticity of the powder particles.

Thus, at high current density further grinding of the deposit is stopped and it becomes possible to obtain powders that are more stable in dispersion.

With intensive hydrogen release the current efficiency decreases and, accordingly, the electric power consumption for obtaining the powder increases.

The effect of temperature on the regularities of the iron ions cathodic reduction, compared with the effect of current density, is of the opposite nature: the increase in temperature decreases the cathodic polarization; the deposits become more coarse-grained, and the limiting current density increases. Such influence of temperature is associated with the increased diffusion rate of iron ions. We observed an insignificant increase in the metal current efficiency with increasing temperature in the range from 313 to $353 \mathrm{~K}$. This is due to the increase in the concentration of metal ions near the cathode zone (Fig. 7).

Thus, the current efficiency is simultaneously significantly affected by two parameters - the temperature and the electrolyte circulation rate.

The content of sulfuric acid in the electrolyte significantly affects only the current efficiency and the cost of electricity. With the increase in electrolyte acidity, the current efficiency of the iron powder decreases significantly. The effect of acidity on the granulometric composition of the iron sediment is insignificant. At the same time, with the increase in sulfuric acid concentration, a certain increase in the dispersion of iron particles is observed.

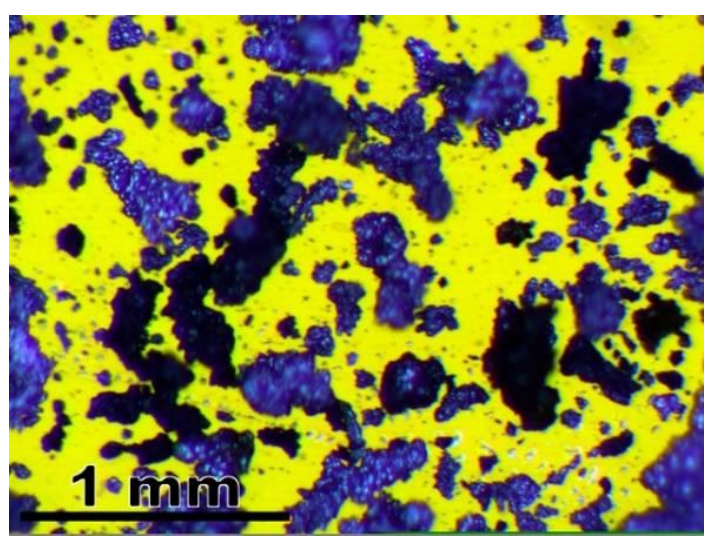

a)

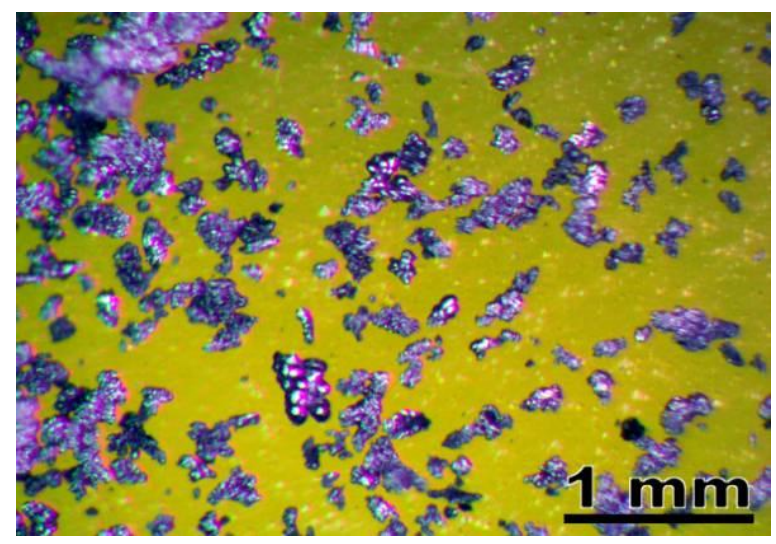

b)

Fig. 4. Micrographs of dispersed iron particles synthesized at electrolyte circulation rates $700 \mathrm{rpm}$ (a) and $100 \mathrm{rpm}$ (b), temperature $313 \mathrm{~K}$, current density $40 \mathrm{~A} / \mathrm{dm}^{2}$ 
Fig. 5. Micrograph of dispersed iron particles synthesized at electrolyte circulation rate $100 \mathrm{rpm}$, temperature $313 \mathrm{~K}$ and current density $60 \mathrm{~A} / \mathrm{dm}^{2}$

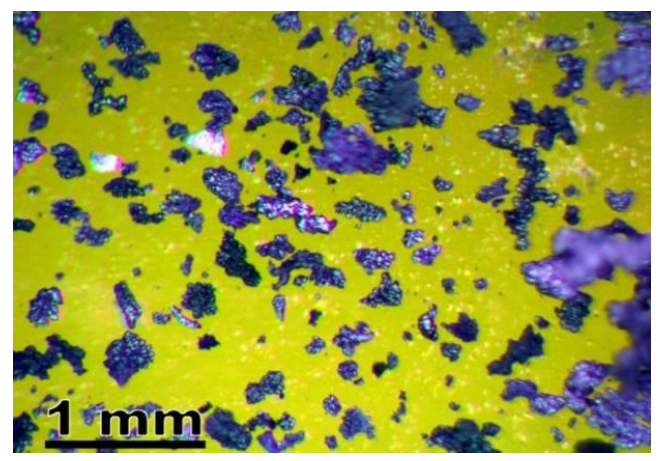

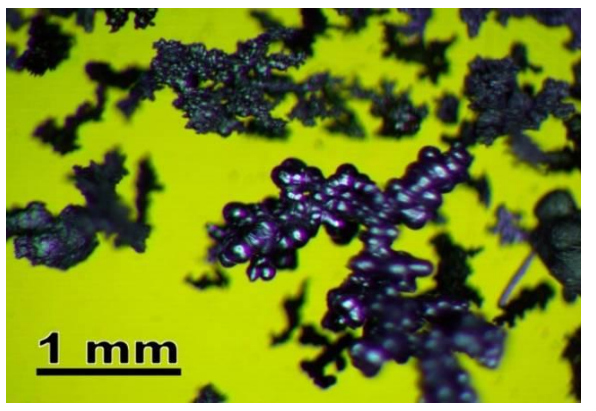

a)

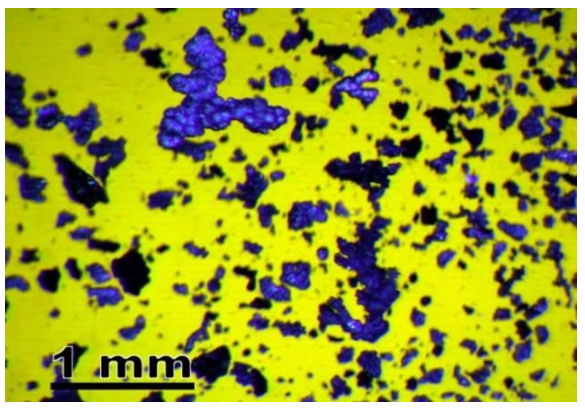

b)

Fig. 6. Micrographs of dispersed iron particles synthesized at current density $40 \mathrm{~A} / \mathrm{dm}^{2}$ (a) and $60 \mathrm{~A} / \mathrm{dm}^{2}$ (b), temperature $313 \mathrm{~K}$, circulation rate $400 \mathrm{rpm}$

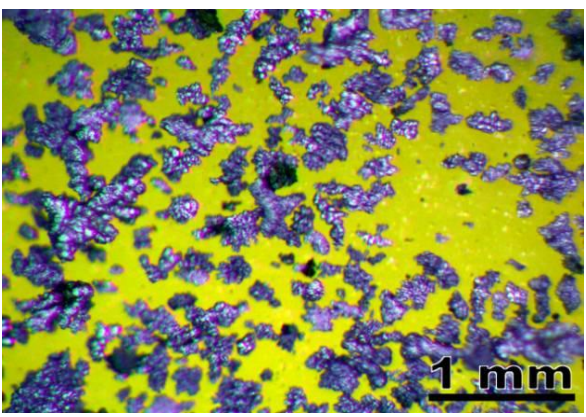

a)

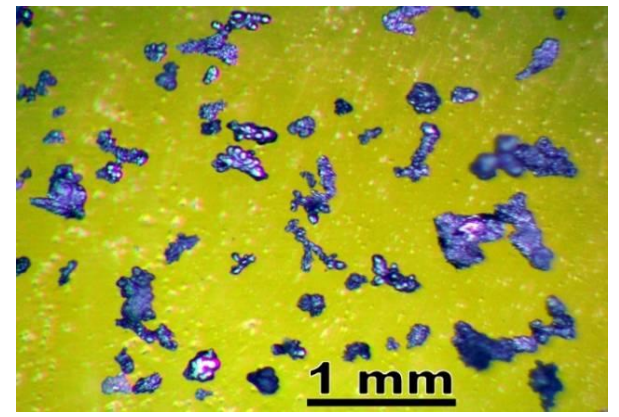

b)

Fig. 7. Micrographs of dispersed iron particles synthesized at electrolyte temperature $353 \mathrm{~K}$ (a) and $313 \mathrm{~K}(\mathrm{~b})$, current density $50 \mathrm{~A} / \mathrm{dm}^{2}$, circulation rate $400 \mathrm{rpm}$

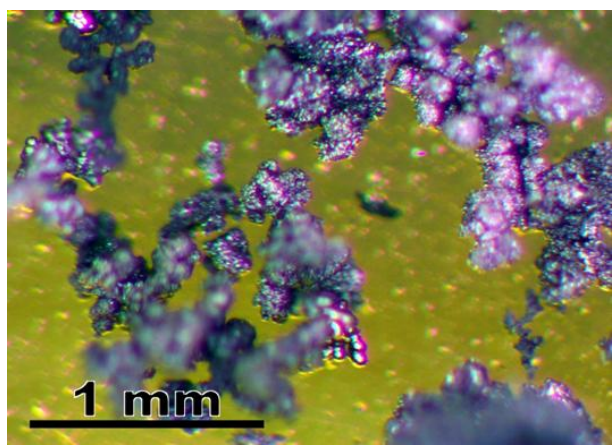

a)

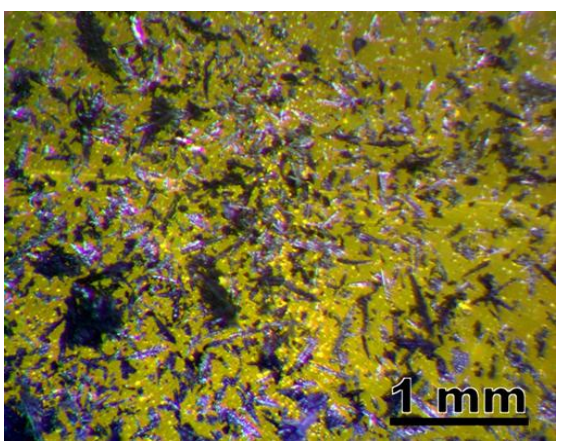

b)

Fig. 8. Micrographs of dispersed iron particles synthesized at iron vitriol concentration in electrolyte of $300 \mathrm{~g} / \mathrm{l}$ (a) and $160 \mathrm{~g} / \mathrm{l}$ (b), current density $50 \mathrm{~A} / \mathrm{dm}^{2}$, circulation rate $400 \mathrm{rpm}$ 
Reduction of iron vitriol concentration within the accepted range of variation and, as a consequence, changes in the content of iron ions in the electrolyte leads to the formation of very thin and light cathode deposits with a bulk density of less than $1.0 \mathrm{~g} / \mathrm{cm}^{3}$. This is due to the fact that with the decrease in the concentration of iron ions in the solution, the conditions for their discharge at the cathode are hampered, the deposit at the cathode grows non-uniformly, and its dendriticity increases [11, 12] (Fig. 8).

\subsection{Effect of Electrodeposition Technological Parameters on the Chemical Properties of Dispersed Iron}

In the first series of experiments we studied the combined effect of current density $\left(i, \mathrm{~A} / \mathrm{dm}^{2}\right)$, electrolyte temperature $\left(t,{ }^{\circ} \mathrm{C}\right)$ and electrolyte circulation rate $(v, \mathrm{rpm})$ on the chemical purity of iron deposit. The chemical purity was evaluated by weight concentration of iron $(C(\mathrm{Fe})$, wt \%) in the deposit. In the second series of experiments the combined effect of current density, concentrations of sulfuric acid $\left(C\left(\mathrm{H}_{2} \mathrm{SO}_{4}\right), \mathrm{g} / \mathrm{l}\right)$, and iron vitriol $\left(C\left(\mathrm{FeSO}_{4}\right), \mathrm{g} / \mathrm{l}\right)$ in the electrolyte on the chemical purity of iron deposit was investigated. The matrices of the experiment plan and experimental results are presented in Tables 4 and 5, respectively.
Based on the results of experimental studies, we created regression models that adequately describe the investigated dependencies:

$$
\begin{gathered}
C(\mathrm{Fe})=93.56-0.25 i-1.02 t-0.12 v- \\
-0.36 i t-0.21 i v+0.19 t v \\
C(\mathrm{Fe})=92.4-0.3 i-2.04 C\left(\mathrm{H}_{2} \mathrm{SO}_{4}\right)+ \\
+0.53 C\left(\mathrm{FeSO}_{4}\right)-0.09 i \cdot C\left(\mathrm{H}_{2} \mathrm{SO}_{4}\right)- \\
-0.76 i \cdot C\left(\mathrm{FeSO}_{4}\right)+0.29 C\left(\mathrm{H}_{2} \mathrm{SO}_{4}\right) \cdot C\left(\mathrm{FeSO}_{4}\right)- \\
-2.173 i \cdot C\left(\mathrm{H}_{2} \mathrm{SO}_{4}\right) \cdot C\left(\mathrm{FeSO}_{4}\right)
\end{gathered}
$$

An analysis of the obtained mathematical models shows that the parameters studied in the second series of experiments have a greater effect on the chemical purity of dispersed iron cathode deposit. The most significant parameter is the concentration of sulfuric acid in the working solution. With the increase in the electrolyte acidity the amount of iron in the cathode deposit is significantly reduced.

The decrease in iron vitriol concentration within the range of variation and, as a consequence, the decrease in the number of iron ions in the electrolyte leads to the formation of very thin cathode deposits with a bulk density not exceeding $1 \mathrm{~g} / \mathrm{cm}^{3}$ and easily oxidizable already during electrodeposition. This is due to the fact that with a decrease in the concentration of metal ions in solution the conditions for their discharge at the cathode are hampered, the deposit at the cathode grows nonuniformly, and its dendriticity increases.

\begin{tabular}{|c|c|c|c|c|}
\hline \multirow{2}{*}{ No. } & \multicolumn{3}{|c|}{ Parameters } & \multirow{2}{*}{$\begin{array}{l}\text { Response function } \\
C(\mathrm{Fe}), \mathrm{wt} \%\end{array}$} \\
\hline & $i, \mathrm{~A} / \mathrm{dm}^{2}$ & $C\left(\mathrm{H}_{2} \mathrm{SO}_{4}\right), \mathrm{g} / \mathrm{l}$ & $C\left(\mathrm{FeSO}_{4}\right), \mathrm{g} / 1$ & \\
\hline 1 & 60 & 0.3 & 300 & 97.568 \\
\hline 2 & 40 & 0.3 & 300 & 97.950 \\
\hline 3 & 60 & 0 & 300 & 97.836 \\
\hline 4 & 40 & 0 & 300 & 97.950 \\
\hline 5 & 60 & 0.3 & 160 & 97.792 \\
\hline 6 & 40 & 0.3 & 160 & 97.001 \\
\hline 7 & 60 & 0 & 160 & 97.868 \\
\hline 8 & 40 & 0 & 160 & 97.950 \\
\hline
\end{tabular}

Table 4

Plan and results of the $1^{\text {st }}$ series of experiments

\begin{tabular}{|c|c|c|c|c|}
\hline \multirow{2}{*}{ No. } & \multicolumn{3}{|c|}{ Parameters } & Response function \\
\cline { 2 - 5 } & $i, \mathrm{~A} / \mathrm{dm}^{2}$ & $t,{ }^{\circ} \mathrm{C}$ & $v, \mathrm{rpm}$ & $C(\mathrm{Fe}), \mathrm{wt} \%$ \\
\hline 1 & 60 & 80 & 700 & 96.235 \\
\hline 2 & 40 & 80 & 700 & 96.111 \\
\hline 3 & 60 & 40 & 700 & 97.836 \\
\hline 4 & 40 & 40 & 700 & 97.950 \\
\hline 5 & 60 & 80 & 100 & 96.992 \\
\hline 6 & 40 & 80 & 100 & 97.005 \\
\hline 7 & 60 & 40 & 100 & 97.868 \\
\hline 8 & 40 & 40 & 100 & 97.950 \\
\hline
\end{tabular}

Table 5

Plan and results of the $2^{\text {nd }}$ series of experiments 


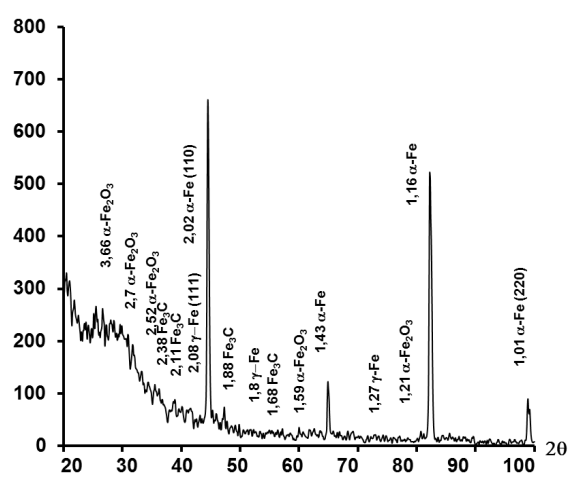

a)

Fig. 9. Diffractograms of iron cathode deposits synthesized in the $2^{\text {nd }}$ series of experiments: No. 1 (a); No. 2 (b); No. 3 (c); No. 5 (d) and No. 6 (e)

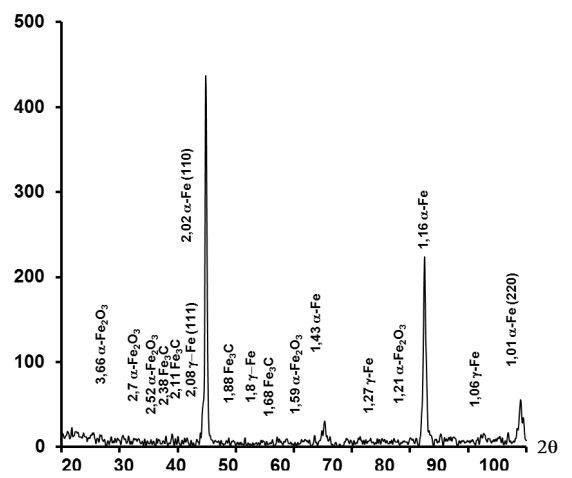

b)

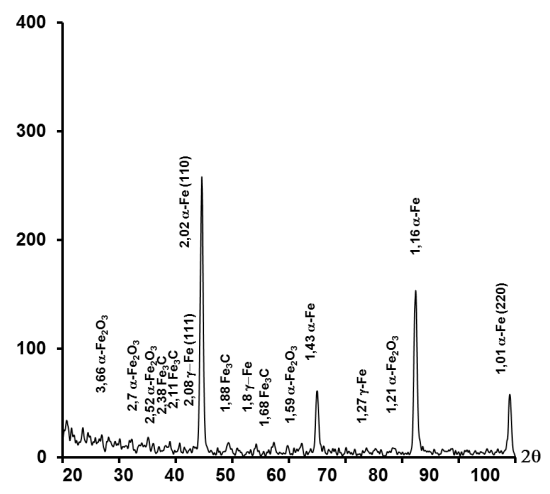

d)

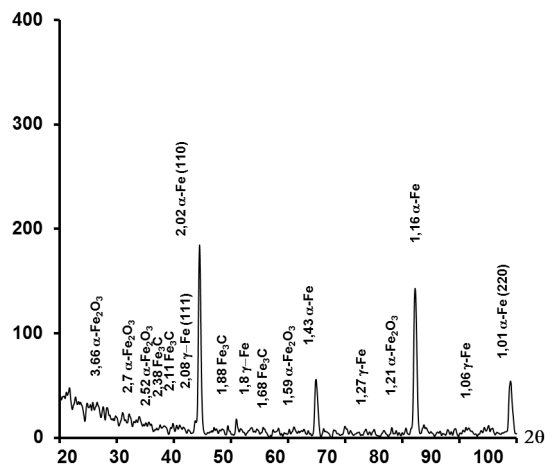

c)

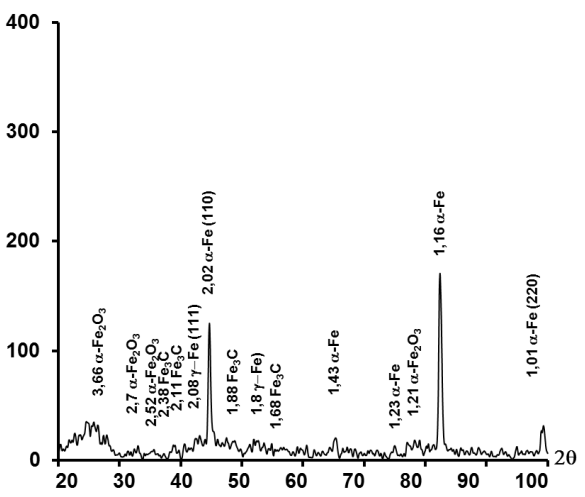

e)

Table 6

Iron content in the powders synthesized in the $2^{\text {nd }}$ series of experiments

\begin{tabular}{|l|c|c|c|c|c|c|c|c|}
\hline No. of experiment & 1 & 2 & 3 & 4 & 5 & 6 & 7 & 8 \\
\hline Iron concentration $C(\mathrm{Fe})$, wt \% & 99.621 & 99.899 & 99.658 & 99.999 & 99.864 & 99.596 & 99.684 & 99.999 \\
\hline
\end{tabular}

The influence of electrolysis technological parameters, studied in the first series of experiments, on the response function is less significant. However, we found the synergistic effect of the combined action of cathodic current density and electrolyte temperature on the chemical purity of the iron deposit. With a simultaneous increase in the values of these parameters, a certain decrease in the iron concentration in the resulting deposit is observed. The increase in electrolyte temperature facilitates deposit oxidation during the deposition of most metals and contributes to the contamination of metals by its impurities that enter the solution with water and from the electrodes. A significant increase in the cathode current density leads to an additional heating of the electrolyte.

The conclusions from the results of the active experiment are confirmed by XRF data (Fig. 9).

Despite the fact that the electrolysis method makes it possible to obtain chemically stable metal powder materials, the XRF data indicate a rather high degree of contamination of the resulting iron deposit by impurities, and, first of all, by iron oxides. Such a level of contamination does not meet the requirements for electrolytic powders, including iron powders.

To increase the chemical purity, the resulting iron cathode deposit was reduced in a hydrogen atmosphere at $1173 \mathrm{~K}$ for $1 \mathrm{~h}$, and then ground in a planetary mill to achieve the desired particle sizes. The iron content in the reduced powders is shown in Table 6 .

\section{Conclusions}

Based on the experimental results the polynomial models were created that adequately describe the interrelationships of the parameters studied. The most significant parameters are the current density, the electrolyte circulation rate and temperature, and the content of iron vitriol in it. The synergistic effect is observed under the combined impact of electrolyte acidity and cathode current density on the iron particle 
morphology. The simultaneous increase in these values results in a considerable enlargement of the cathode iron particles. The electrolyte composition has a much greater effect on the chemical purity of the dispersed iron cathode deposit compared with the electrolysis technological parameters. The sulfuric acid concentration in the working solution is the most significant factor. With increasing acidity of electrolyte, the iron content in the cathode deposit decreases.

The synergistic effect is observed under the combined impact of cathode current density and electrolyte temperature on the chemical purity of iron deposit. The simultaneous increase in these values increases concentration of impurities in the resulting deposit.

The technological factors of the electrolysis process in the investigated ranges of variation can effectively influence electrodeposition process of iron dispersed cathode deposit, as well as a complex of physical and technological properties of the resulting electrolytic iron powder.

\section{References}

[1] Ramakrishnan P.:Conserv. Recycling, 1983, 6, 49.

https://doi.org/10.1016/0361-3658(83)90016-4

[2] Gaballah N., Zikry A., Khalifa M. et al.: Open J. Inorg. Non-

Metal. Mater., 2013, 3, 23.

https://doi.org/10.4236/ojinm.2013.33005

[3] Bagatini M., Zymla V., Osório E., Vilela A.: ISIJ Int., 2011, 51,

1072. https://doi.org/10.2355/isijinternational.51.1072

[4] Benchiheub O., Mechachti S., Serrai S., Khalifa M.: J. Mater.

Environ. Sci., 2010, 1, 267.

[5] Fleischanderl A.: Gorham/Intertech's $13^{\text {th }}$ Int. Iron and Steel

Development Forum, Antwerp., - 11-14 May 1998. - P. 45-50.

[6] El-Hussiny N., Mohamed F., Shalabi M.: Sci. Sintering, 2011, 43, 21. https://doi.org/10.2298/SOS1101021E

[7] El-Hussiny N., Shalabi M.: Powder Technol., 2011, 205, 217.

https://doi.org/10.1016/j.powtec.2010.09.017
[8] Kuntyi O.: Electrokhimia ta Morphologiya Dispersnykh Materialov. NULP, Lviv 2008.

[9] Vnukov A., Golovachev A., Asmolkov V.: Metallozanvstvo ta Term. Obrobka Mater., 2012, 3-4, 75.

[10] Pinchuk S., Vnukov A.: Mellaurg. Gornorudn. Prom., 2013, 6, 85.

[11] Pavlovic M., Popov K.: Metal Powder Production by Electrolysis [in:] Electrochemistry Encyclopedia, 2005, 37-41.

[12] Popov K., Pavlovic M.: Electrodeposition of Metal Powders with Controlled Particle Grain Size and Morphology. [in:] White R., Conway B., Bockris J. (eds), Modern Aspects of Electrochemistry.

Springer, Boston, MA, vol 24, 299-391.

https://doi.org/10.1007/978-1-4615-3022-0_6

[13] Antony L., Reddy G.: JOM, 2003, 55, 14. https://doi.org/10.1007/s11837-003-0153-4

[14] Nurmi J., Tratnyek G., Sarathy V. et al.: Environ. Sci.

Technol., 2005, 39, 1221. https://doi.org/10.1021/es049190u

[15] Adrien J., LeDuc M., Loftfield R., Vaaler L.: Electrochem.

Soc., 1959, 106, 659. https://doi.org/10.1149/1.2427467J

Received: June 18, 2018 / Revised: August 08, 2018/ Accepted: September 12, 2018

\section{ОСОБЛИВОСТІ ОДЕРЖАННЯ \\ ЕЛЕКТРОЛІТИЧНОГО ЗАЛІЗНОГО ПОРОШКУ З ВІДХОДІВ ПРОКАТНОГО ВИРОБНИЦТВА}

\footnotetext{
Анотація. Одержано електролітичний порошок заліза з регульованою формою і розміром частинок, з необхідними структурними, фізичними та функціональними властивостями. Прочес електролітичного осадження дисперсного заліза проводили з використанням сталевого розчинного анода й титанового катода. Електроліт - сульфатний; форма катода пластина; час електролізу - 1 година. Експериментальні дослідження проведені із застосуванням кореляиійно-регресійного аналізу. Методом оптичної мікроскопії визначені середні розміри і морфологію частинок. Отримані поліноміальні моделі, які адекватно описують встановлені взасмозв'язки досліджуваних параметрів.
}

Ключові слова: відходи прокатного виробництва, окалина, залізний порошок, швидкість ииркуляиії, електроосадження, щиільність струму, морфологія часток, розмір частинок. 